\title{
PERTUMBUHAN TINGGI TANAMAN SAWI HIJAU MELALUI PEMBERIAN CAMPURAN MEDIA TANAM BERBAHAN APU-APU
}

\author{
Edi Maryono, Didin Syafruddin, Markus Iyus Supiandi, Yakobus Bustami, Yasinta Lisa \\ Program Studi Pendidikan Biologi, STKIP Persada Khatulistiwa Sintang, Sintang \\ Email: ybustami07@gmail.com
}

\begin{abstract}
ABSTRAK
Pertumbuhan tinggi tanaman sawi hijau (Brassica Sinensis L) menjadi salah satu faktor penentu dalam meningkatkan produktivitas tanaman sawi hijau. Penelitian ini bertujuan untuk mengetahui peningkatan pertumbuhan tinggi tanaman sawi hijau (Brassica sinensis L) dengan pemberian campuran media tanam berbahan apu-apu (Pistia stratiotes). Pendekatan yang digunakan berupa pendekatan kuantitatif dengan metode penelitian eksperimen. Rancangan dalam penelitian ini menggunakan Rancangan Acak Lengkap (RAL) dan setiap perlakuan terdiri dari 6 ulangan. Data yang diukur adalah pertumbuhan tinggi tanaman sawi hijau. Alat pengumpul data mengunakan lembar observasi dan dokumentasi berupa foto. Analisis data menggunakan analisis deskriptif dan inferensial. Analisis inferensial menggunakan uji anova dan dilanjutkan dengan uji Least Significant Difference (LSD). Hasil penelitian menunjukkan bahwa pemberian pupuk organik Apu-Apu memberikan pengaruh yang signifikan terhadap pertumbuhan tinggi tanaman sawi hijau. Pertumbuhan tanaman sawi hijau dengan pemberian pupuk organik Apu-Apu menghasilkan nilai reratatertinggi sebesar5,22 cm. Hasil ini diperkuat dengan analisis anova yang menunjukkan bahwa nilai probalilitas lebih kecil dari nilai alpa (nilai: $p<0,05$ ). Selanjutnya, hasil uji LSD menunjukkan bahwa pupuk organik berbahan Apu-Apupada perlakuan kelima (450 gram) berbeda nyatadengan perlakuan lainnya. Dengan demikian, perlakuan kelima dengan dosis 450 gram merupakan dosis yang paling baik atau optimal dalam meningkatkan pertumbuhan tinggi tanaman sawi hijau.
\end{abstract}

Kata kunci: Media tanam, sawi hijau, pertumbuhan,tanaman apu-apu.

\section{PENDAHULUAN}

Sayuran merupakan komoditas penting dalam mendukung ketahanan pangan nasional. Komoditas ini memiliki keragaman yang luas dan berperan sebagai sumber karbohidrat, protein nabati, vitamin, dan mineral yang bernilai ekonomi tinggi. Sawi hijau merupakan salah satu jenis sayur yang digemari oleh masyarakat Indonesia yang berasal dari Asia.Tanaman sawi hijau (Brassica sinensis L.) adalah tanaman yang cocok di tanam pada tanah yang gembur, banyak mengandung humus,subur,serta pembuangan airnya baik. Derajat keasaman tanah yang optimal untuk pertumbuhannya adalah antara $6-7 \mathrm{pH}$ sehingga sawi hijau dapat ditanam secara monokultur maupun tumpang sari.

Umumnya tanaman sawi hijau dapat tumbuh pada tempat yang bersuhu panas maupun dingin. Tanaman sawi hijau juga dapat ditanam pada dataran rendah maupun tinggi,namun pertumbuhan dan produksi sawi hijau lebih baik ditanam pada dataran tinggi $100-500 \mathrm{~m}$ dpl,dengan kondisi tanah gembur, banyak mengandung humus, subur dengan drainase baik. Menurut Cahyono, pertumbuhan sawi yang baik membutuhkan suhu udara yang berkisar antara $19{ }^{\circ} \mathrm{C}-21^{\circ} \mathrm{C}$ [1]. Tanaman ini selain tahan terhadap suhu panas (tinggi) juga mudah berbunga dan menghasilkan biji secara alami pada kondisi iklim tropis Indonesia [2]. Menurut Ohorella, umur panen sawi hijau relatif pendek yakni 3040 hari setelah tanam dan hasilnya memberikan keuntungan yang memadai [3].

Selain itu, tanaman sawi hijau bila ditinjau dari aspek ekonomis dan bisnisnya layak untuk dikembangkan atau diusahakan untuk memenuhi permintaan konsumen. Menurut Gardner, faktorfaktor yang mempengaruhi pertumbuhan diantaranya bahan organik serta unsur hara esensial yang cukup [4]. Bahan organik dan unsur hara tersebut terkandung di dalam media tanam, sehingga 
pertumbuhan dan perkembangan tanaman sangat bergantung pada jenis media tanam yang digunakan. Saat ini untuk memenuhi kebutuhan bahan organik dan unsur hara untuk mendukung pertumbuhan tanaman para petani masih bergantung pada pupuk kimia semacam Urea, Za, dan NPK. Penggunaan pupuk kimia memiliki peranan dalam mempercepat masa tanam karena kandungan haranya bisa diserap langsung oleh tanah.Namun disisi lain, penggunaan pupuk kimia justru akan menimbulkan dampak yang negatif bila digunakan dalam jangka waktu yang lama, karena tanaman tidak bisa menyerap $100 \%$ pupuk kimia yang selalu akan ada residu atau sisanya yang nantinya akan merusak kesuburan tanah dan lingkungan sehingga akan menyebabkan para petani akan ketergantungan pada pupuk kimia untuk mendukung kesuburan tanamannya.

Mengatasi permasalahan tersebut, maka perlu dilakukan pemupukan dengan menggunakan pupuk organik yang mudah dibuat dan ramah lingkungan.Salah satunya adalah dengan membuat pupuk organik dari tanaman apu-apu (Pistia stratiotes) yang ramah lingkungan tetapi dapat meningkatkan produktifitas tanaman sawi hijau. Pemanfaatan tanaman apu-apu ke dalam bentuk pupuk organik dipilih karena lebih mudah memperoleh bahan pembuatan pupuk organiknya, mudah dalam peroses pembuatannya, dan tidak memerlukan waktu yang lama untuk menghasilkan pupuk organik serta mudah terserap oleh tanaman karena unsur-unsur di dalamnya sudah terurai.

Percepatan pengguraian tanaman apu-apu menjadi pupuk organik dapat dilakukan dengan menggunakan Efective Microorganism (EM4) yang banyak mengandung unsur hara dan mikroorganisme yang berfungsi untuk mempercepat pertumbuhan tanaman sawi hijau. Mengingat kandungan unsur hara dalam pupuk organik dari tanaman apu-apu banyak mengandung unsur-unsur hara esensial, maka dipandang sangat penting untuk dilakukan penelitian untuk menguji dosis pupuk organik dari tanaman apu-apu dengan berbagai tingkat perlakuan untuk meningkatkan pertumbuhan tinggi tanaman sawi hijau. Penelitian ini bertujuan untuk melihat seberapa besar pengaruh pupuk organik dari tanaman apu-apu (Pistia stratiotes)terhadap pertumbuhan tanaman sawi hijau dan mencari penggunaan takaran pupuk organik yang paling efektif dan efisien.

\section{METODE PENELITIAN}

Penelitian ini menggunakan metode penelitian eksperimen dengan bentuk penelitian true experiment. Penelitian eksperimen (experimental research) bertujuan untuk melihat pengaruh perlakuan terhadap perilaku yang timbul sebagai akibat perlakuan,sedangkan true experimen digunakan untuk mengontrol semua variabel luar yang mempengaruhi jalannya eksperimen. Rancangan penelitian yang digunakan dalam penelitian ini adalah Rancangan Acak Lengkap (RAL) yang dapat dilihat pada Tabel 1.

Tabel 1. Bentuk Rancangan Acak Lengkap (RAL)

\begin{tabular}{ccccccc}
\hline \multirow{2}{*}{ perlakuan } & \multicolumn{7}{c}{ ulangan } \\
\cline { 2 - 7 } & U1 & U2 & U3 & U4 & U5 & U6 \\
\hline P1 & P1U1 & P1U2 & P1U3 & P1U4 & P1U5 & P1U6 \\
P2 & P2U1 & P2U2 & P2U3 & P2U4 & P2U5 & P2U6 \\
P3 & P3U1 & P3U2 & P3U3 & P3U4 & P3U5 & P3U6 \\
P4 & P4U1 & P4U2 & P4U3 & P4U4 & P4U5 & P4U6 \\
P5 & P5U1 & P5U2 & P5U3 & P5U4 & P5U5 & P5U6 \\
\hline
\end{tabular}

Keterangan:

P1 $($ Kontrol 1$)=$ Pupuk organik apu-apu $=0 \%=0 \mathrm{gr}$

P2 $($ Perlakuan 2) $=$ Pupuk organik apu-apu $=15 \%=150 \mathrm{gr}$

P3 $($ Perlakuan 3$)=$ Pupuk organik apu-apu $=25 \%=250 \mathrm{gr}$

P4 $($ Perlakuan 4$)=$ Pupuk organik apu-apu $=35 \%=350 \mathrm{gr}$

P5 $($ Perlakuan 5$)=$ Pupuk organik apu-apu $=45 \%=450 \mathrm{gr}$

U1 = Ulangan $1 \quad$ U4 = Ulangan 4

U2 = Ulangan $2 \quad$ U5 = Ulangan 5

U3 = Ulangan $3 \quad$ U6 = Ulangan 6

Pertumbuhan Tinggi Tanaman...

Maryono, dkk 
Alat yang digunakan dalam penelitian ini berupa: parang, ember, cangkul, papan, timbangan, skop, palu, paku, poleybag, pengaris, bolpoin, pupuk organik apu-apu, EM4, air, gula, sendok, bibit sawi hijau, tanah. Adapun prosedur dalam penelitian ini meliputi tahapan pembuatan pupuk organik dari tanaman apu-apudan penanaman sawi hijau. Adapun prosedur kerja tersebut dapat dilihat pada Tabel 2 dan 3 berikut ini.

Tabel 2. Prosedur Pembuatan Pupuk Organik dari Tanaman Apu-Apu

\begin{tabular}{cl}
\hline No & \multicolumn{1}{c}{ Prosedur } \\
\hline 1. & Siapkan bahan dan alat. \\
2. Siapkan ember besar dan masukkan apu-apu kering yang sudah dipotong kecil kecil. Ember \\
digunakan sebagai wadah untuk pembuatan pupuk organik. \\
3. Campurkan EM4 dengan air dan gula dengan perbandingan 10 sendok EM4, 20sendok gula \\
dan 2 liter air. \\
4. Siramkan campuran EM4, gula dan air kepada apu-apu yang sudah dimasukkan kedalam \\
5. Aduk rata dan tutup rapat dan didiamkan selama \pm 14 hari.
\end{tabular}

Tabel 3. Prosedur Penanaman Sawi Hijau (Brassica sinensis L)

\begin{tabular}{|c|c|}
\hline No & Prosedur \\
\hline 1. & Menyiapkan alat dan bahan yang digunakan selama proses penelitian \\
\hline 2. & $\begin{array}{l}\text { Terlebih dulu bibit sawi hijau di semai pada kotak kayu dengan ukuran } 60 \times 60 \mathrm{~cm} \text {. Penyemaian } \\
\text { dilakukan selama } 5 \text { hari. }\end{array}$ \\
\hline 3. & $\begin{array}{l}\text { Menyiapkan media tanam yang akan digunakan dengan cara mengisi polybag dengan tanah } \\
\text { yang sudah dicampurkan dengan pupuk organik apu-apu. Biarkan polybag selama 1-2 hari } \\
\text { sebelum ditanam agar unsur hara yang diperlukan terbentuk. }\end{array}$ \\
\hline 4. & $\begin{array}{l}\text { Penyusunan polybag sesuai dengan denah agar pengamatan dapat dilakukan dengan mudah } \\
\text { dan cepat. }\end{array}$ \\
\hline 5. & $\begin{array}{l}\text { Pencabutan bibit dilakukan dengan hati-hati. Kemudian buat lubang pada polybag yang } \\
\text { sudah di isi dengan tanah sedalam 3-6 } \mathrm{cm} \text { menggunakan tongkat kayu atau dengan jari } \\
\text { tangan. Kemudian masukkan bibit kedalamnya. }\end{array}$ \\
\hline 6. & $\begin{array}{l}\text { Penyiraman dilakukan sebanyak } 2 \times \text { sehari atau lebih di sesuaikan dengan kondisi cuaca. } \\
\text { Pembersihan hari gulma dan penggemburan dilakuakan setiap } 7 \text { hari sekali. }\end{array}$ \\
\hline 7. & Masa panen sawi hijau umumnya setelah tanam berusia $30-40$ hari \\
\hline 8. & Pengamatan dimulai dari hari ke-7 sampai hari ke-30. \\
\hline
\end{tabular}

Parameter yang diukur dalam penelitian ini adalah tinggi tanaman sawi hijau. Analisis data menggunakan analisis deskriptif dan inferensial. Analisis inferensial menggunakan uji anova dan dilanjutkan dengan uji Least Significant Difference(LSD) pada taraf $0,05 \%$ untuk melihat beda nyata dari setiap perlakuan. Analisis data dihitung menggunakan perhitungan SPSS versi 23 .

\section{HASIL DAN PEMBAHASAN}

Hasil yang diperoleh dalam penelitian ini merupakan semua data yang dikumpulkan selama penelitian dilapangan. Pengukuran tinggi tanaman dilakukan pada saat tanaman berusia 30 hari setelah tanam. Berdasarkan hasil analisis deskriptif menunjukkan bahwa nilai rerata pertumbuhan tinggi tanaman sawi hijau setelah 30 hari cenderung meningkat. Hasil analisis deskriptif pada Tabel 4. menunjukkan bahwa peningkatan pertumbuhan tinggi tanaman sawi hijau yang paling tinggi ditemukan padaperlakuan P5 (45\%) sebesar5,22 cm sedangkan pertumbuhan nilai rerata paling kecil pada K1 (0\%) sebesar 3,35cm. Hasil analisis deskriptif secara lengkap dapat dilihat pada Tabel 4. 
Tabel 4.Hasil Analisis Deskriptif Nilai Rerata Tinggi Tanaman Sawi Hijau

\begin{tabular}{ccc}
\hline No & Perlakuan & Nilai Rerata \\
\hline 1 & P1 & 3,35 \\
2 & P2 & 3,72 \\
3 & P3 & 4,53 \\
4 & P4 & 4,43 \\
5 & P5 & 5,22 \\
\hline \multicolumn{2}{c}{ Total } & 12,2900 \\
\hline
\end{tabular}

Hasil analisis anovapada Tabel 5 menunjukkan bahwa pemberian pupuk organik berbahan apu-apu ( $p: 0,000)$ berpengaruh signifikan terhadap pertumbuhan tinggi tanaman sawi hijau (nilai: $p<0,05)$, sehingga perlu dilakukan uji lanjut dengan uji Least Significant Difference(LSD) pada taraf $5 \%$ untuk melihat perbedaan dari setiap perlakuan. Hasil uji LSD dapat dilihat pada Tabel 6.

Tabel 5. Hasil Anova Rancangan Acak Lengkap Tinggi Tanaman Sawi Hijau Dependent Variable: hasil

\begin{tabular}{|c|c|c|c|c|c|}
\hline Source & $\begin{array}{l}\text { Type III Sum of } \\
\text { Squares }\end{array}$ & df & Mean Square & $\mathrm{F}$ & Sig. \\
\hline Corrected Model & $11,882^{\mathrm{a}}$ & 1 & 11,882 & 29,458 & 000 \\
\hline Intercept & 46,349 & 1 & 46,349 & 114,912 & ,000 \\
\hline perlakuan & 11,881 & 1 & 11,881 & 29,458 & ,000 \\
\hline Error & 11,294 & 28 & ,403 & & \\
\hline Total & 565,050 & 30 & & & \\
\hline Corrected Total & 23,175 & 29 & & & \\
\hline
\end{tabular}

a. R Squared $=, 513$ (Adjusted R Squared $=, 495$ )

Tabel 6. Hasil uji LSDpada taraf 5\% Tinggi Tanaman Sawi Hijau

\begin{tabular}{ccccccc}
\hline \multirow{2}{*}{ Perlakuan } & ulangan & Nilai rerata & Std deviasi & Nilai Cor & Notasi LSD \\
\hline P1 & 0 gram & 3,3500 &, 30166 & 9,8833 & a & \\
P2 & 150 gram & 3,7167 &, 39707 & 10,7333 & a & \\
P3 & 250 gram & 4,5333 &, 67132 & 12,8667 & & b \\
P4 & 350 gram & 4,4333 &, 86641 & 12,9167 & b & \\
P5 & 450 gram & 5,2167 &, 78337 & 15,0500 & & c \\
\hline
\end{tabular}

Berdasarkan hasil uji LSD pada Tabel 6 menunjukkan bahwa pertumbuhan tinggi tanaman sawi hijau pada perlakuan 1 dan 2 tidak berbeda nyata namun berbeda nyata dengan perlakukan 3 dan 4 . Lebih lanjut, perlakuan 3 dan 4 berbeda nyata dengan perlakuan 5. Perlakuan 5 memiliki nilai terkoreksi lebih tinggi dibandingan dengan perlakukan yang lainnya. Dengan demikian, perlakuan 5 dengan dosis 450 gram merupakan dosis yang paling baik untuk pertumbuhan tinggi tanaman sawi hijau.

Berdasarkan hasil analisis deskriptif menunjukkan bahwa nilai rerata pertumbuhan tinggi tanaman sawi hijau setelah 30 hari cenderung meningkat dengan nilai rerata tertinggi sebesar (P5) sebesar $5,22 \mathrm{~cm}$ dan terendah (P1) sebesar $3,35 \mathrm{~cm}$. Hasil penelitian ini menunjukkan bahwa pertumbuhan tanaman sawi hijau dengan pemberian pupuk organik berbahan apu-apu dapat meningkatkan pertumbuhan sawi hijau. Hasil penelitian ini sejalan dengan penelitian yang dilakukan oleh Baharuddin yang menunjukkan bahwa pemberian bahan organik berpengaruh sangat nyata terhadap jumlah daun tanaman sawi hijau[5].

Hasil analisis anova menunjukkan bahwa terdapat pengaruh yang signifikan pemberian pupuk organik berbahan apu-apu terhadap tinggi tanaman sawi hijau (nilai: $p<0,05$ ). Hasil penelitian ini 
sejalan dengan penelitian Rukmana yang mengemukakan bahwa bahan organik merupakan sumber hormon nabati yang paling baik dalam mengoptimalkan pertumbuhan dan produksi tanaman sawi hijau (Brassica juncea L)[6]. Hal ini terbukti dengan tingginya hasil panen sawi hijau (Brassica juncea $L$ ) yang diberi hormon nabati dibandingkan dengan yang tidak diberi perlakuan.Lebih lanjut, penelitian Ratih menunjukkan bahwa pemanfaatan tanaman apu (Pistia Stratiotes) dan tanaman kiambang (Salvinia molesta) terbukti dapat meningkatkan pertumbuhan tanaman selada (Lactuca sativa) secara hidroponik[7]. Selanjutnya pada penelitian Baharuddin mengemukakan bahwa pemberian bahan organik berpengaruh sangat nyata terhadap jumlah daun tanaman sawi hijau $B$. Juncea $L[5]$.

Adanya pengaruh yang signifikan pupuk organik berbahan apu-apu disebabkan karena pupuk organik dari tanaman apu-apu mengandung unsur hara yang diperlukan oleh tanaman unsur hara seperti unsur makro dan mikro. Menurut Musnamar pupuk organik mengandung unsur hara makro ( $\mathrm{N}, \mathrm{P}, \mathrm{K})$ dan mikro ( $\mathrm{Ca}, \mathrm{Mg}, \mathrm{Fe}, \mathrm{Mn}, \mathrm{Bo}, \mathrm{S}, \mathrm{Zn}$ dan $\mathrm{Co}$ ) yang dapat memperbaiki struktur dan porositas tanah[8]. Bahan organik dapat bereaksi dengan ion logam membentuk senyawa kompleks sehingga ion-ion logam yang bersifat racun terhadap tanaman atau menghambat penyediaan unsur hara misalnya Al, Fe dan $\mathrm{Mn}$ dapat berkurang [9]. Sedangkan menurut Wiroatmodjo dalam penelitiannya menyatakan bahwa penggunaan pupuk organik akan mendorong perkembangan akar dan berfungsi menyerap hara dan air untuk pertumbuhan tanaman[10]. Ashari juga menyatakan media yang ideal haruslah mampu memberikan aerasi yang cukup, mempunyai daya pegang air dan drainase yang baik serta bebas dari jamur dan bakteri pathogen[11].

Hasil uji lanjut LSD menunjukkan bahwa nilai rerata pertumbuhan tinggi tanaman sawi hijau terkoreksi pada perlakuan 1 dan 2 tidak berbeda nyata namun berbeda nyata dengan perlakukan 3 dan 4. Lebih lanjut, perlakuan 3 dan 4 berbeda nyata dengan perlakuan 5 . Perlakuan 5 memiliki nilai terkoreksi lebih tinggi dibandingan dengan perlakukan yang lainnya. Dengan demikian, perlakuan 5 dengan dosis 450 gram merupakan dosis yang paling baik atau optimal dalam meningkatkan pertumbuhan tinggi tanaman sawi hijau. Hal ini sejalan dengan yang diungkapkan oleh Roe dan Nurhikmatbahwa pemberian kompos optimal dapat meningkatkan pertumbuhan dan produksi tanaman diantaranya jagung, mentimun, kobis, wortel, cabe, semangka dan sawi[12,13].

\section{SIMPULAN}

Berdasarkan hasil penelitian dan pembahasan maka dapat ditarik kesimpulan bahwa: (1) pertumbuhan tinggi tanaman sawi hijau (Brassica sinensis L) melalui pemberian pupuk organik berbahan apu-apu menunjukkan pertumbuhan yang lebih baik daripada yang tidak diberikan pupuk organik apu-apu; (2) pemberian pupuk organik berbahan apu-apu(p:0,000) berpengaruh signifikan terhadap pertumbuhan tinggi tanaman sawi hijau (nilai: $p<0,05$ ); (3) perlakuan kelima (dosis 450 gram) pemberian pupuk organik berbahan apu-apu (Pistia stratiotes) merupakan yang paling baik dan optimal dalam meningkatkan pertumbuhan tinggi tanaman sawi hijau (Brassica sinensis $\mathrm{L}$ ).

Berdasarkan hasil penelitian ini masih banyak yang dapat dikembangkan dari tanaman apuapu. Adapun saran dari penelitian ini adalah sebagai berikut: (1) penelitian selanjutnya agar melakukan penelitian dengan dosis perlakuan, jenis tanah, dan tempat yang berbeda terhadap pertumbuhan tinggi tanaman sawi hijau (Brassica sinensis L); (2) pengomposan apu-apu (Pistia stratiotes) dilakukan dengan jangka waktu yang lama supaya mendapat hasil yang baik; (3) penelitian selanjutnya agar dapat mengujicobakan pupuk organik apu-apu (Pistia stratiotes) pada jenis tanaman lainnya.

\section{DAFTAR PUSTAKA}

[1]. Cahyono, B., 2003,Teknik dan strategi budidaya sawi hijau, Yoyakarta,Yayasan Pustaka Nusantara.

[2]. Haryanto, E., dan Suhartini, T., 2002,Sawi dan selada, Jakarta, Penebar Swadaya.

[3]. Ohorella, Z., 2012,Pengaruh Dosis Pupuk Organik Cair (POC) terhadap Pertumbuhan dan Produksi Tanaman Sawi Hijau (Brassica sinensis L.), Jurnal Agroforestri. Vol VII No. 1 Hal 44-49. 
[4]. Gardner, F.P.R.B., Pearce, dan Mitchell, R. L., 1991,Fisiologi Tanaman Budidaya, Jilid pertama, Penerjemah, Herawati Susilo, Jakarta, UI-Press.

[5]. Baharuddin,2012,NutrisiLabiota, Makassar, Pusat Penelitian dan Pengembangan Divisi Bioteknologi Pertanian UNHAS

[6]. Rukmana, R., 1994, Bertanam Petsai dan Sawi, Kanisius, Yogyakarta, Salisbury.

[7]. Ratih, 2009, Phytoremediasi Greywater dengan Tanaman Kayu Apu (Pistia Stratiotes) dan Tanaman Kiambang (Salvinia Molesta) Serta Pemanfaatannya Untuk Tanaman Selada (Lactuca Sativa) Secara Hidroponik. Bogor, Fakultas Pertanian Institut Pertanian Bogor.

[8]. Musnamar, E.I., 2003,Pupuk Organik Padat Pembuatan dan Aplikasinya, Jakarta, Penebar Swadaya.

[9]. Setyorini, D., 2005, Pupuk Organik Tingkatkan Produksi Tanamandan Warta Penelitian dan Pengembangan Pertanian, Jakarta, Gramedia Pustaka Utama.

[10]. Wiroatmodjo, E.,Sulistyono., dan Hendrinova., 1990,Pengaruh Berbagai Pupuk Organik dan Pupuk Daun terhadap Pertumbuhan dan Hasil Rimpang Jahe (Zingiberofficinale Rosc).Buletin Agronomivol. XIX, no (I), hal 33-88.

[11]. Ashari, S., 1995, Hortikultura, Jakarta, Universitas Indonesia.

[12]. Roe, N.E., 1998, Compost Utilization for Vegetable and Fruit Crops, Washington, Island Press.

[13]. Nurhikmat, 2009, Dekomposer limbah jerami padi pada usaha tani padi sawah, Malang, Bayu Media Publishing. 